\title{
Andrzej S. Dyszak, Jezzyk ojczysty w szkole podstawowej $i$ w gimnazjum. Komentarz językoznawczy do podstawy programowej $w$ zakresie kształcenia językowego, Bydgoszcz 2002, s. 211
}

Podstawa programowa ${ }^{1}$ obowiązująca od września 1999 roku przyniosła istotne zmiany w zakresie kształcenia językowego w szkole podstawowej i w gimnazjum. Istotę tych przemian najogólniej można określić jako podporządkowanie nauki o języku sprawnościom językowym uczniów. Na temat reformy kształcenia językowego wypowiadało się wielu językoznawców i wydaje się, że większość z nich akceptuje jej kierunek. Pojawiły się jednak głosy, że niepokojąca jest ogólnikowość treści językowych zawartych w Podstawie programowej, co może grozić ich pomijaniem $w$ dydaktyce ${ }^{2}$. Najwięcej obaw wśród językoznawców budziła perspektywa braku podstawowej wiedzy gramatycznej $u$ absolwentów szkół średnich.

Książka Andrzeja S. Dyszaka jest publikacją, w której autor stara się zdefiniować obszar edukacyjnych powinności polonisty $w$ zakresie wiedzy językowej uczniów. Należy podkreślić, iż A. Dyszak od lat popularyzuje wiedzę o języku wśród nauczycieli i wyjaśnia zawiłości szkolnej nauki o języku³ ${ }^{3}$ Adresatem omawianej książki są nauczyciele

1 Podstawa programowa kształcenia ogólnego dla sześcioletnich szkót podstawowych i gimnazjów, „Dziennik Ustaw” nr 14 z 23.02.1999 r.

2 Por. Stanowisko Rady Wydziału Polonistyki Uniwersytetu Warszawskiego w sprawie sposobu wprowadzania $w$ życie szkolnej reformy nauczania (ze szczególnym uwzględnieniem przedmiotu "język polski"), „Poradnik Językowy” 2000, z. 5, s. 39-41; Stanowisko Rady Naukowej Instytutu Języka Polskiego PAN w Krakowie w sprawie standardów wymagań egzaminacyjnych, "Język Polski" 2001, z 4, s. 285-286.

3 A. Dyszak jest autorem wielu artykułów poświęconych dydaktyce nauki o języku, m.in.: Jak interpretować niektóre hasła programowe $w$ dziale "Nauka o języku", "Język Polski w Szkole dla klas IV-VIII" 1993, z. 5, s. 7-19; Wybrane zagadnienia z zakresu słowotwórstwa w nauczaniu szkolnym, "Język Polski w Szkole dla klas IV-VIII" 1996, z. 2, s. 33-40; Z dydaktyki składni język polskiego. Drugorzędne części zdania a zwiazki syntaktyczne, "Język Polski" 1997, z. 4-5, s. 323-330; O składni w szkole podstawowej - uwagi i propozycje, [w:] Z Teorii i Praktyki Dydaktycznej Języka Polskiego, t. 15, red. E. Polański, Z. Uryga, Katowice 1999. 
języka polskiego w szkole podstawowej i w gimnazjum, a efekt swej pracy autor nazywa próbą wskazania, czego [...] powinno się uczyć dzieci i młodzież $w$ zakresie kształcenia językowego zgodnie $z$ duchem wdrażanej od roku 1999 reformy szkolnictwa (s. 9).

Książka stanowi omówienie zagadnień językoznawczych "wywołanych" niejako przez Podstawę programowq. We wstępie autor przypomina dyskusję nad celami nauczania gramatyki w szkole, opowiada się za jej sfunkcjonalizowaniem, a następnie dokonuje przeglądu zawartych $\mathrm{w}$ Podstawie programowej treści kształcenia językowego w zreformowanej szkole podstawowej i w gimnazjum. Wokół tych treści zorganizowana została część właściwa książki: dwa rozdziały poświęcone omówieniu zagadnień językowych $\mathrm{z}$ Podstawy programowej oraz rozdział dotyczący kształcenia językowego $\mathrm{w}$ wybranych programach nauczania.

$\mathrm{W}$ rozdziale Jezzyk ojczysty $w$ szkole podstawowej autor omawia zagadnienia składniowe (wypowiedzenia oznajmujące, pytające i rozkazujące, zdanie i równoważnik zdania, zdanie pojedyncze, związki wyrazów w zdaniu), fleksyjne (odmienne i nieodmienne części mowy, podstawowe kategorie fleksyjne), leksykalne (związki znaczeniowe między wyrazami), słowotwórcze (podstawowe pojęcia słowotwórcze, budowa słowotwórcza wyrazów, kategorie i typy słowotwórcze) oraz fonetyczne (rodzaje głosek, akcent wyrazowy i intonacja). Rozdział ten zamyka omówienie odmian polszczyzny oraz gwary bydgoskiej jako przykładu języka regionu.

W rozdziale Język ojczysty $w$ gimnazjum omówione zostały składniowe funkcje części mowy, wypowiedzenia złożone (typy zdań złożonych, imiesłowowy równoważnik zdania składowego, interpunkcja w wypowiedzeniu złożonym), przekształcanie wypowiedzeń (konstrukcje czynne i bierne) oraz szczegółowe zagadnienia słowotwórcze (m.in. typy formantów, ich funkcje i produktywność, typologia wyrazów złożonych, przymiotniki i przysłówki $w$ stopniu wyższym i najwyższym), fleksyjne (budowa form czasowników, rzeczowników i przymiotników), leksykalne (treść i zakres znaczeniowy wyrazów, wyrazy ogólne i szczegółowe, wyrazy konkretne i abstrakcyjne, neologizmy) i fonetyczne (rodzaje upodobnień, uproszczenia). Rozdział zamykają rozważania nad komunikacją językową (funkcje języka, style i stylizacja). 
Uzupełnieniem książki jest rozdział Ksztatcenie jezykowe w programach nauczania. Autor porównuje $\mathrm{w}$ nim sposób rozwinięcia treści z zakresu kształcenia językowego Podstawy programowej $\mathrm{w}$ dwóch programach do szkoły podstawowej ${ }^{4}$ i dwóch programach do gimnazjum ${ }^{5}$. Na koniec przedstawia własną propozycję rozkładu treści kształcenia językowego dla poszczególnych klas szkoły podstawowej i gimnazjum. Całość zamyka bibliografia oraz indeks terminów językowych.

Omawiana publikacja stanowi zatem adresowaną do nauczycieli propozycję uszczegółowienia i rozwinięcia treści z zakresu wiedzy o języku zawartych w Podstawie programowej. Autor, posiadający wieloletnie doświadczenie nauczycielskie, wysuwa wobec dotychczasowej dydaktyki szkolnej sensowne postulaty (proponuje m.in. rozszerzenie listy czasowników o formach nieregularnych, których odmianę należy ćwiczyć) i dostrzega te miejsca w nauce o języku, które mogą sprawiać problemy dydaktyczne (np. wyjaśnia, że rzeczowniki nie odmieniają się przez rodzaj, ale rodzaj jest im przypisany). Należy jednak podkreślić, iż - podobnie jak każda interpretacja zapisów programowych - propozycja A. Dyszaka jest propozycją autorską. Oznacza to, że zarówno zakres proponowanych wymagań, jak i interpretacja zjawisk językowych nie są jedynymi możliwymi sposobami odczytania zapisów programowych. O tym, czy przyjęte rozwiązania można uznać za trafne, decyduje ich spójność z założonymi celami i dostosowanie do potrzeb czytelnika. W tym względzie ocena Języka ojczystego... nie wypada entuzjastycznie.

Autor we wstępie do swej książki deklaruje się jako zwolennik gramatyki funkcjonalnej (cele poznawcze szkolnej nauki o jezyku winny być podporzadkowane doskonaleniu mowy ucznia, s. 17) i krytyk dotychczasowego sposobu nauczania: $Z$ a naczelny btad $w$ dotychczasowej szkolnej nauce o jezzyku trzeba uznać to, iż uczeń był zmuszony opanować strukturę gramatyki, rozumianej jako zasady rzqdzqce w jezzyku, która to struktura stawała

4 Są to programy D. Chwastek i K. Bogdan, Oglądam świat. Program nauczania języka polskiego w klasach IV-VI szkoty podstawowej oraz M. Kasprzyk i A. Zalewskiej, Program nauczania języka polskiego $w$ klasach IV-VI szkoty podstawowej. Obydwa programy opublikowano [w:] Programy nauczania języka polskiego w klasach IV-VI szkoty podstawowej, Poznań 1999.

5 Są to: Program nauczania języka polskiego $w$ gimnazjum. Stentor 2 - Kto czyta, nie błądzi, praca zbiorowa, Warszawa 1999 oraz program A. Gis, Zrozumieć słowo. Program nauczania języka polskiego w klasach I-III gimnaz jum, Poznań 1999. 
się w praktyce szkolnej strukturq przedmiotu (s. 17). Czytelnik dowiaduje się, że nie należy uczyć według struktury przedmiotu i... otrzymuje publikację, która tak właśnie jest skonstruowana: dwa środkowe rozdziały, które z racji objętości (s. 39-163) należy uznać za część właściwą książki, stanowią wykład zorientowany przedmiotowo. Czytelnik jest informowany, że trzeba zmienić sposób nauczania, ale poza wstępnymi deklaracjami nie otrzymuje zbyt wielu wskazówek informujących, jak ten cel osiągnąć. Sygnalizowaną niespójność ilustruje sposób zinterpretowania przez autora zapisów programowych dotyczących związków składniowych.

W Podstawie programowej znajduje się stwierdzenie, że uczeń szkoły podstawowej ma umieć dostrzegać związki wyrazów w zdaniu. A. Dyszak interpretuje ten zapis zgodnie $\mathrm{z}$ tradycją i daje wykład poświęcony związkowi głównemu oraz związkom zgody, rządu i przynależności. Skoro nauczyciel ma wskazywać reguły rządzące językiem, żeby poprawić sprawność językową ucznia (takie ujęcie jest zgodne z Podstawq programowq i autor jednoznacznie się za nim opowiada), to zwracanie uwagi na to, jak łączyć wyrazy, by tworzyć poprawne związki składniowe, jest kształcące (oczywiście w szkole podstawowej owo wskazywanie, jak wyrazy łączą się w zdaniu, nie powinno odbywać przez wykład typu: żeby poprawnie zbudować związek między rzeczownikiem a przymiotnikiem, należy dostosować formy gramatyczne przymiotnika do form gramatycznych rzeczownika). Podstawowa wątpliwość dotyczy tego, czy sprawności językowej służy umiejętność klasyfikowania materiału językowego na tradycyjne związki składniowe. Wątpliwość tę wzmacnia świadomość kontrowersji, jakie wiążą się z nauczaniem tradycyjnej składni. Wiadomo, że opis budowy zdania w konwencji składni tradycyjnej $\mathrm{w}$ wielu punktach opiera się na arbitralnych rozwiązaniach. W konsekwencji operowanie tym opisem wymaga nie tyle logiki myślenia, ile pamięciowego opanowania pewnych reguł. Właśnie dlatego dotychczasowy sposób nauczania syntaktyki jest krytykowany ${ }^{6}$.

6 Por. np. U. Andrejewicz, Uwagi o nauczaniu składni $w$ szkole, [w:] Z problematyki kształcenia językowego, T. II. Składnia - teoria a praktyka szkolna i akademicka, red. H. Sędziak, Białystok 2002, s. 221-228; M. Ruszkowski, Relacja między pojęciami "zdanie nierozwinięte" - "zdanie rozwinięte" $w$ modelu składni tradycyjnej, "Język Polski” LXXXI1-2, s. 76-81; Wróblewska T., Wróblewski P., Nauczanie 
A. Dyszak, omawiając zagadnienia składni tradycyjnej, tłumaczy miejsca wątpliwe, przedstawia autorskie klasyfikacje (np. klasyfikację typów orzeczeń, s. 85), ale w żaden sposób nie wyjaśnia, jak funkcjonalnie uczyć tej składni w zreformowanej szkole. Co prawda autor zastrzega we wstępie, że jego książka nie jest poradnikiem dydaktycznym, ale $\mathbf{z}$ drugiej strony sam przyznaje, że $\mathbf{w}$ szkolnej nauce problemem nie jest to, czy uczyć gramatyki, ale to, jak ta nauka ma przebiegać i właśnie to, jak uczyć, jest największym wyzwaniem (s. 17).

Niekiedy autor proponuje inne od zakorzenionych w tradycji szkolnej interpretacje zjawisk językowych, ale zdaje się wtedy zapominać, kogo uczynił adresatem swej książki. Za przykład niech posłuży tu proponowana przez A. Dyszaka typologia wyrazów złożonych, czyli pochodzących od co najmniej dwóch podstaw słowotwórczych. Autor przypomina, że $\mathrm{w}$ dotychczasowej praktyce szkolnej wydzielało się zrosty, złożenia i zestawienia, informuje, że w nowszych pracach językoznawczych wydziela się jedynie złożenia (termin ten obejmuje jednocześnie pojęcie zrostów) i skrótowce, gdyż zestawienia traktowane są jako frazeologizmy z pogranicza składni i leksyki, a następnie łączy obydwie klasyfikacje i proponuje podział na złożenia (tu: złożenia właściwe i zrosty), zestawienia i skrótowce (s. 110-111). Podział oczywiście jest logiczny, ale brakuje uzasadnienia, dlaczego taka typologia wyrazów złożonych w dydaktyce ma być lepsza od dotychczasowej. Autor traktuje adresata swej książki - nauczyciela - tak, jak dawniej traktowało się ucznia: miał przyjąć do wiadomości to, co przekazywał mu nauczyciel. Czytelnik Jezzyka ojczystego... także ma przyjąć proponowane rozwiązania bez wdawania się $\mathrm{w}$ "zbędne" uzasadnienia czy dyskusje nad alternatywnymi propozycjami.

Sposób prowadzenia wykładu powoduje niekiedy trudności ze zrozumieniem zaleceń autora dotyczących czego i jak uczyć. Lakoniczność autorskiego komentarza bywa tak daleko posunięta, że może doprowadzić do nieporozumień. Przykładem takiej sytuacji jest opis zależności

składni w zreformowanej szkole - uwagi i propozycje, [w:] Nie bez znaczenia. Prace ofiarowane Zygmuntowi Saloniemu z okazji jubileuszu 15000 dni pracy naukowej, Białystok 2001, s. 235-256; P. Zbróg, Związi zgody, rzqdu i przynależności - dyskusyjne problemy, [w:] Z problematyki ksztatcenia językowego, T. II. $[\ldots]$, s. $63-72$. 
między głównymi częściami zdania za pomocą pozbawionego komentarza schematu, którym w literaturze językoznawczej przedstawia się analizę akomodacyjną7 (s. 37). Schemat jest mylący $z$ tego względu, że autor łączy analizę fleksyjną $\mathrm{z}$ analizą składniową: jedna strzałka (bez oznaczeń) biegnie od tematu czasownika do tematu rzeczownika, a charakteryzowane zależności dotyczą samych końcówek fleksyjnych. Graficzny obraz związków składniowych sugeruje, że liczba i rodzaj rzeczownika narzucają liczbę i rodzaj czasownikowi, a osoba czasownika narzuca rzeczownikowi przypadek (tu: mianownik).

Autor zdaje się zapominać, do kogo adresuje swą publikację również wtedy, gdy jego komentarz jest zbyt naukowy i zupełnie mija się z potrzebami polonisty. Przykładem takiego nietrafionego komentarza jest definicja głoski: Głoska to najmniejszy dźwięk, wyodrębniany przez człowieka jego aparatem stuchowym (uchem), a powstajacymi w procesie mówienia jako wynik pobudzonych impulsem $z$ mózgu określonych ruchów pewnych narzqdów mowy $i$ odpowiedniego położenia innych spośród nich $w$ czasie wydechu (s. 58) ${ }^{8}$. Proponowana definicja, poza niezręcznością na poziomie składniowym i stylistycznym, jest nieprecyzyjna (ludzkie narządy mowy mogą tworzyć nieskończoną ilość dźwięków, a tylko niektóre spośród nich nazywamy głoskami).

Czasem trudno dociec, jaki sposób wyjaśniania zjawisk językowych proponuje autor nauczycielom. Przykładowo, do kategorii gramatycznych werbalnych należą: aspekt, strona, tryb, czas, osoba (s. 46). W komentarzu autor pisze: $W$ języku polskim aspekt nie jest właściwie kategoriq fleksyjnq, a raczej jest kategoriq klasyfikacyjnq czasowników [...]. Strona [...] jest $w$ zasadzie kategoriq składniowq (s. 47). Kilka stron dalej w rozdziale poświęconym gimnazjum pojawia się stwierdzenie, iż kategorie fleksyjne czasownika to: osoba, czas, tryb i strona (s. 121). W tabeli, w której autor prezentuje własną propozycję rozkładu treści kształcenia językowego dla szkoły podstawowej i gimnazjum, wśród podstawowych kategorii

7 Zob. np. Z. Saloni, M. Świdziński, Składnia wspótczesnego języka polskiego, Warszawa 1998, s. 229; R. Grzegorczykowa, Wykłady z polskiej składni, Warszawa 1998, s. 73.

8 Taką definicję głoski (już bez błędu składniowego) podają autorzy skryptu dla studentów filologii polskiej (por. A. Dyszak, E. Laskowska, M. Święcicka, Fonetyczny i fonologiczny opis wspótczesnej polszczyzny, Bydgoszcz 1991, s. 41), ale tam stanowi ona punkt wyjścia do dalszych rozważań nad istotą głoski i do budowania kolejnych definicji. 
fleksyjnych wymieniony został również aspekt (s. 199). Przypuszczam, że po takim wyjaśnieniu nauczyciel będzie miał wątpliwości, jak ma uczyć.

Źródłem kłopotów ze zrozumieniem wywodu jest m.in. nietradycyjna, tzn. niezadomowiona $w$ tradycji szkolnej terminologia. Autor operuje terminami kategoria gramatyczna (s. 46, 48, 121), fleksyjna (s. 48, 121), klasyfikacyjna (s. 47, 48), składniowa (s. 47), słowotwórcza (s. 48), ale nie podaje ich definicji i nie określa wzajemnych zależności. Odczytanie znaczenia tych terminów bywa utrudnione, np. kategoria gramatyczna raz jest pojęciem nadrzędnym w stosunku do kategorii fleksyjnej (por. s. 48, 209), a innym razem wydaje się pojęciem synonimicznym (s. 121). Ponadto termin kategoria stowotwórcza występuje w dwóch znaczeniach, z których jedno ma w tradycji szkolnej (i nie tylko szkolnej) znaczenie ustabilizowane: kategoria słowotwórcza to klasa wyrazów o wspólnym uogólnionym znaczeniu (s. 57)9 , a drugie jest dla nauczycieli zupełnie nowe (Fleksyjna kategoria liczby przystuguje wtaściwie tylko tzw. rzeczownikom policzalnym, ale jest $w$ swej istocie kategoriq stowotwórczq: zmiana formy nie powoduje zmiany funkcji w wypowiedzeniu [...] (s. 48)).

$Z$ proponowaną przez A. Dyszaka terminologią wiąże się jeszcze jedna drobna uwaga. Warto rozważyć zasadność nazywania rzeczowników typu dyżurny rzeczownikami występującymi w formach przymiotnikowych (s. 135). W tradycji szkolnej takie rzeczowniki określano mianem rzeczowników odmieniających się jak przymiotniki. Dawna nazwa wydaje się bardziej informatywna dla ucznia.

Dyskusyjne są proponowane $\mathrm{w}$ omawianej książce niektóre interpretacje zjawisk językowych, np. traktowanie derywatu słabiej jako pochodnego od przymiotnika staby (s. 118) (bez odpowiedzi pozostaje pytanie, jaka parafraza mogłaby uzasadnić proponowaną interpretację); stwierdzenie, że w formach liczby pojedynczej rzeczowników nieodmiennych typu muzeum nie można wyróżnić końcówek (s. 136) (analiza form liczby mnogiej rzeczownika muzeum pozwala przecież wskazać, gdzie przebiega granica między tematem fleksyjnym a końcówką); nazywanie wartościami gramatycznymi kategorii osoby zaimków ja, ty,

9 Wydaje się, że właśnie to znaczenie autor uznaje za podstawowe, gdyż w Indeksie terminów językowych przy terminie kategoria stowotwórcza znajduje się odesłanie jedynie do s. 57 . 
on, ona, ono, my, wy, oni, one (s. 46). Zdziwienie budzi potraktowanie form bezosobowych czasowników zakończonych na -no, -to (s. 126) oraz bezokoliczników i imiesłowów przymiotnikowych i przysłówkowych (s. 128) jako formacji słowotwórczych. O ile takie traktowanie imiesłowów przymiotnikowych ma swą tradycję w pracach językoznawczych, o tyle operowanie terminem "przyrostek słowotwórczy" w opisie form typu bie-c, napisa-wszy czy licz-ono wymaga głębszego uzasadnienia, gdyż taka interpretacja nie jest powszechna. Ponadto, skoro formy bezosobowe oraz bezokoliczniki i imiesłowy zostały potraktowane jako formacje słowotwórcze, niekonsekwencją jest omawianie ich budowy w rozdziale Fleksyjne czq̨stki budowy wyrazów.

Ogólnie sposób wyjaśniania budowy morfologicznej czasowników jest bardzo niekonsekwentny. Najpierw autor radzi unikać wyjaśniania budowy tematu form czasownikowych i wprowadzania pojęcia przyrostka fleksyjnego (s. 105), ale kilka stron dalej (s. 122), choć nie używa terminu "przyrostek fleksyjny”, mówi o fleksyjnych cząstkach budowy czasowników (także tych, których temat "poszerza się" w pewnych formach). W różnych miejscach tekstu pojawiają się następujące zapisy form czasownika: śpiew-am (s. 43), czyta-m (s. 121), pisat-em, pisat-a-m, pisał-eś, pisał-a-ś (s. 122), pisała-m (s. 124).

Pora na krótkie podsumowanie. To dobrze, że na rynku wydawniczym pojawia się pozycja, której zadaniem ma być pomoc polonistom w zdefiniowaniu zadań i zakresu kształcenia językowego w zreformowanej szkole. Poloniści bardzo potrzebują takiej pomocy. Niedobrze, że otrzymują pracę niekonsekwentną i niejednoznaczną $\mathrm{w}$ proponowanych rozwiązaniach oraz zbyt lakoniczną, jeśli idzie o nowsze interpretacje zjawisk językowych. Ostatecznie o tym, czy Język polski w szkole podstawowej $i$ w gimnazjum okaże się pomocą przydatną, zadecydują sami adresaci tej książki - nauczyciele-poloniści. 